\author{
https://doi.org/10.34142/23129387.2019.60.02 \\ УДК 159.9 \\ ORCID: 0000-0003-1421-0554
}

\title{
ПРОЦЕСИ СИНТЕЗУ В ПСИХОЛОГІЇ (ВІДКРИТТЯ У НАУКОВІЙ ТВОРЧОСТІ Л.С. ВИГОТСЬКОГО)
}

\author{
Віталій Г. Панок, \\ доктор психологічних наук, професор, \\ Украйнський науково-методичний центр практичної психології $i$ \\ соиіальної роботи НАПН України, Київ \\ E-mail: panokvitaly@ukr.net
}

В результаті аналізу творчості Л.С. Виготського доведено, щцо синтез є одним з ключових методологічних засновків на якому побудована його теорія. Ключовим питанням, яке залишив по собі дослідник майбутнім психологам, ие питання про те де відбувається синтез - у реальному психічному житті людини, чи синтез $є$ всього лише теоретичним конструктом.

Застосування методологї синтезу знань (Г.П. Щедровищький) до теоретичного узагальнення у психології дозволило розвинути ідеї Л.С. Виготського стосовно розуміння сутності проблеми синтезу. Зокрема: синтез $\epsilon$ реальним психологічним механізмом, який забезпечує функиіонування психіки $i$ розвитку особистості (індивідуальності); синтез є иентральним методологічним підгрунтям у прикладній психологї без якого остання втрачає смисл; синтез $\epsilon$ ключовим методологічним принщипом у прочесі професійної підготовки практикуючого психолога.

Ключові слова: теорія Л.С. Виготського, синтез, методологія, особистість, психічні прочеси, прикладна психологія, механізми синтезу. 


\section{The Process of Synthesis in Psychology (Discovery in scientific work of L. Vygotsky) \\ Vitalii H. Panok, \\ Doctor of psychological sciences, professor, Ukrainian Science-Methodological Center for Applied Psychology and Social Work, National Academy of Pedagogical Sciences' of Ukraine.}

The Aim of the article: the statement of the problem of synthesis in modern scientific and applied psychology and the definition of ways of its application in theory and in practice.

Results: By the analysis of L. Vygotsky' work, it is proved that synthesis is one of the key foundations on which his theory is based. The key question which the researcher left to future psychologists is where the synthesis takes place: in the real mental life of a person or it's just a theoretical construct.

The application of the methodology of synthesis of knowledge (G. Shchedrovytsky) to the theoretical generalization in psychology made it possible to develop the ideas of L. Vygotsky regarding the understanding of the essence of the synthesis problem. In particular: synthesis is a real psychological mechanism which ensures the functioning of the psyche and development of personality (individuality); synthesis is a central methodological foundation in applied psychology without which the latter loses its' meaning; synthesis is a key methodological principle of professional training of practical psychologist.

Conclusions: According to L.S. Vygotsky, synthesis is a methodological "key" that can solve the crisis problem in psychology. The concept of synthesis is used in science as a real process; as processes ensuring the creation of qualitatively new products; as a component of the philosophical methodology of cognition. Processes of synthesis - these are the real processes that occur in the mental reality of man as a level of elementary mental processes and functions, and at the level of personality, individuality. Synthesis, a synthetic approach to the realization of the facts of human mental life is the main methodological principle of applied psychology. The basis of professional training of a practical psychologist (psychologist-practitioner) is the formation of his synthetic abilities, the ability to synthesize various theoretical representations and diverse facts and the results of clinical diagnosis into a coherent picture of being and development of human personality.

Keywords: L. Vygotsky' theory, synthesis, methodology, personality, mental processes, applied psychology, means of a synthesis. 


\section{Вступ.}

Актуальність дослідження наукової спадщини

\section{Л.С. Виготського.}

Характеризуючи стан справ у психології перших десятиліть ХХ століття всесвітньо відомий психолог Л.С. Виготський говорив про глибоку кризу. Ця криза, на думку дослідника, полягала у тому, що колись цілісна психологічна наука змушена розділятись на дві. Головною причиною, джерелом, такого розділення у психології «є принцип практики, який тисне на психологію». Результатом такого «розділення» стало велике розмаїття психологічних теорій $\mathrm{i}$, мабуть, не менша кількість психологічних практик.

Наразі маємо початок XXI століття. I одним 3 питань, які можуть собі поставити психологи, $є$ питання чи подолана та криза, про яку писав Л.С. Виготський? Чи питання про кризу не є наразі актуальним? Чи криза у психології взагалі не існує? А якщо існує, то у чому іiі суть? В широкому потоці літератури 3 історії i теорії психології поняття «криза» майже не застосовується при характеристиці сучасного стану психологічної теорії і практики. Множаться теорії і концепції, виникають i зникають школи та напрями психологічного практикування, публікуються результати експериментальних досліджень. Деякі наукові школи нагадують клуби письменників, що пишуть на психологічну, або - навколопсихологічну, тематику. Деякі течії у психологічній практиці нагадують нам псевдо-релігійні спільноти або структури мережевого маркетингу. Годі вже й говорити про надзвичайно строкату картину категорійно-поняттєвого апарату, коли одне психічне явище називається різними термінами у залежності від «школи».

Підсумовуючи необхідно констатувати, що сьогодні існує не дві психології - наукова і прикладна, а незчисленна кількість психологій. При цьому, деякі з них фактично психологіями не $\epsilon$. 
Усе це приводить нас до висновку про існування чітко вираженої кризи в сучасній психології. При цьому ця криза залишається неподоланою ще 3 початку минулого століття. Скажемо більше: вона поглиблюється.

Сутність кризи у психології, яка почалася у минулому столітті і продовжується дотепер, визначається проблемами у методології. Точніше - невизначеністю методологічних засад психологічних концепцій і психологічних практик. Предмет психології (як наукової, так і практичної) - психіка, попри всю різноманітність, багатогранність і багатовекторність розвитку, являє собою певну онтологічну цілісність. Отже і наукові підходи, теорії, концепції, школи, психологічні практики мають хоча б узгоджуватись, координуватись між собою таким чином, щоб відображати у тій чи іншій мірі предмет психології або хоча б окремі його компоненти. У протилежному випадку, як це $€$ зараз, усе це буде нагадувати вавилонську башту. Сучасна психологія, як і майже сто років тому, знов шукає шляхів подолання кризи.

Одним із можливих шляхів подолання кризи у психології може бути синтез окремих парціальних знань, методів, теорій, результатів експериментів та досвіду практиків. Саме синтез, на наш погляд, може бути тим методологічним засновком на основі якого $є$ можливою побудова системи психологічних знань, теорій і методів, визначення їх ролі і місця у загальній картині дослідження психічного. Психологія потребує зараз прориву, переходу на новий, вищий щабель розуміння психічного. А цей перехід стає можливим, на нашу думку, тільки шляхом синтезу психологічних знань і методів.

Саме синтез Л.С. Виготський вважав тим методологічним «ключем», який здатний розв'язати проблему кризи у психології. Нажаль, не всі ідеї «Моцарта у психології» знайшли належний відгук серед сучасників і послідовників. Ідея синтезу, на наш погляд, якраз і відноситься до категорії недосліджених 
(маловивчених), яка, тим не менш, є надзвичайно актуальною i перспективною відносно формування методологічних засад сучасної психології.

Отже, об'єктом даної роботи є явище синтезу в психології, який розглядається і як методологічний засновок і як реальний механізм психічного розвитку (процес). Предметом роботи $\epsilon$ визначення сутності, функцій і ролі синтезу у побудові системи психологічних знань i практики. Метою даної роботи $\epsilon$ постановка проблеми синтезу в сучасній науковій і прикладній психології та визначення шляхів його застосування як в теорії, так і на практиці. Завдання: 1) на основі теоретичного аналізу робіт Л.С. Виготського визначити його розуміння сутності поняття «синтез» у психології; 2) уточнити розуміння синтезу як реального процесу (процесів), що відбувається у фізичній i метафізичній площинах, i в якості одного 3 гносеологічних методів, що може бути застосований у науковій і прикладній психологіі; 3) розвинути теоретичні уявлення про синтез у психології та показати його значення, роль і функції як у теоретичному, так і у прикладному аспектах.

\section{Результати і обговорення.}

Поняття синтезу у творчості Л.С. Виготського.

Вибудовуючи теоретико-методологічні засади прикладної психології неможливо не звернутися до творчості теоретиків педології, адже сучасна прикладна психологія - це, по суті, педологія початку XX століття. Наші багаторічні дослідження у цій царині (Панок, 1999; В.Г. Панок, 2010, 2017) дали змогу нам більше заглибитись в історичний матеріал, більш прискіпливо проаналізувати теоретичні роботи педологів (М.Я. Басова, Дж. Болдуїна, П.П. Блонського, Л.С. Виготського, С.Г. Геллерштейна, О.С. Залужного, А.Б. Залкінда, С.С. Моложавого, В.П. Протопопова, Г.С. Костюка, Ф.Е. Рибакова, І.П. Соколянського, С. Холла та ін..). Навіть одну 3 перших наших робіт у цьому напрямі (Панок, 1999) ми хотіли 
присвятити вітчизняним педологам, оскільки саме їх творчість надихнула нас на іiї створення.

Глибоке дослідження творчості Л.С. Виготського дозволило нам знайти практично невідому сьогодні його роботу «К вопросу о педологии и смежных с нею науках». Ця робота не увійшла до шеститомного «Зібрання творів», що вийшло у світ у 1984 році (Выготский, 1984). Натомість, в останньому, шостому, томі у Списку робіт автора вона зазначена під № 122 (с. 372) i відноситься до 1931 року (Выготский, 1984). Публікувалась вона як стаття одночасно в журналі «Педологія» № 3, С. 52 - 58, i № $7-8$, С.12 - 22, та в журналі «Психологія» під заголовком «К вопросу о психологии и педологии» 1931, т. 4, вип. 1, С. 78 100. Нині цей матеріал доступний на ресурсі (Педологія ...) для всіх, хто бажає з ним ознайомитися.

В одній з робіт останніх років (Панок, 2017) ми здійснили спробу розвинути ідеї Л.С. Виготського, які були висловлені в його роботі 1931 року, обгрунтувавши «принцип синтезу» в якості головного принципу прикладної психології. Ми, фактично, протиставили принцип аналізу, який є притаманним здебільшого науковій методології, принципу синтезу, який, на нашу думку, $є$ притаманним у більшій мірі психології прикладній.

У свій час, в силу різних причин ми не змогли дати розгорнутий аналіз ідеї Л.С. Виготського щодо ролі і місця синтезу в психології. Настав час надолужити. Отже, розглянемо уважніше вже згадувану роботу Л.С. Виготського.

Як уже зазначалось, стаття Л.С. Виготського присвячена визначенню ролі і місця педології, нової на той час науки про дитину, в системі людинознавчих наук, i особливо - iï співвідношенню із психологією. «Надзвичайно показовим у методологічному i історичному відношенні $\epsilon$ процес виникнення педології як єдиної самостійної науки. Хто правильно зрозуміє чому і як виникла педологія на Заході і в 
Америці, чому і як вона фактично померла там, той знайде ключ до проблеми, що нас цікавить, співвідношення педології i суміжних 3 нею наук» (цит. за Педологія...). Адже питання про методологічну перебудову якої-небудь науки закономірно стикається 3 питанням про співвідношення між науками. Педологія визначає себе не як (окрему) часткову науку в ряду інших (окремих) часткових наук про дитину, а як загальну науку про розвиток дитини. На підтвердження своїх слів автор адресується до робіт Стенлі Холла. Він говорить, що однією 3 найперших проблем, що постала перед американським дослідником в процесі методологічного оформлення ним нової науки, була проблема співвідношення її з іншими науками.

Характеризуючи сучасний йому стан кризи в зарубіжній педології Л.С. Виготський говорить: «глибоке протиріччя, що виникло між стихійною історичною тенденцією до породження педології з глибин окремих наук, що вивчали окремі аспекти дитячого розвитку, і між методологічним оформленням цієї тенденції уже з самого початку прирікало на невдачу спробу створити нову науку. Тут емпірична наука постала перед роковим вибором - ій необхідно було або перескочити вище, ніж дозволяє іï власна методологія, або залишитися у такому ж первісному стані і взагалі відмовитися від стрибка, який став життєво необхідним для цілої низки наук про дитину» (Педологія...).

Аналіз сучасних йому робіт в галузі педології, фізіології, психології і соціології, матеріалів I педологічного конгресу (1911 рік, Брюссель) дозволив Л.С. Виготському визначити основну причину кризи педології - стара аналітична методологія. «Уся суть справи полягає у тому, - констатує дослідник, - що наука, яка грунтується на формально-логічній основі, неодноразово стикається з фактами i, зокрема, з фактами зв'язку, які виходять за межі іiі розуміння» (Педологія...). Дослідник встановлює факт зв'язку між окремими явищами i 
процесами, але він не може пояснити природу, витоки i механізми цього зв'язку, оскільки залишається у межах однієї вузької наукової парадигми, аналітичної методології, формальної логіки.

Далі автор визначає сутність педології як специфічної науки про розвиток особистості: «сама педологія прагне до вивчення не стільки нового ряду явищ, що залишались до іii виникнення поза увагою якої-небудь науки, скільки ставить за мету дослідження тих складних зв'язків, співвідношень i залежностей між окремими сторонами і процесами дитячого розвитку, які покладені в його основу і визначають його як якісно своєрідне, таке, що не зводиться до суми процесів, що його складають, підпорядковане своїм особливим специфічним, йому притаманним закономірностям ціле» (Педологія...). Говорячи про «якісно нове ціле», що не зводиться до простої суми процесів, які його складають, Л.С. Виготський, фактично, заявляє про синтетичну природу молодої науки - педології. Більш того, синтез знань суміжних 3 педологією наук (психологія, вікова фізіологія, соціологія та ін..) як раз і є суттю педології, тим новим знанням про розвиток дитини, яке одержують дослідники в результаті здійснення процедур синтезу, теоретичного узагальнення емпіричного матеріалу. Синтез якраз і $є$ тим механізмом, що забезпечує вихід за межі конкретної науки, дає можливість пояснити ті зв'язки, що не знаходять свого пояснення у межах окремої (часткової) науки.

«Досліджуючи в якості головного свого об'єкту побудову і плин цілісного процесу дитячого розвитку, педологія, тим самим, при визначенні свого предмету і методу не може не прагнути виявлення тих відносин, що існують між об'єктом, що нею досліджується - процесом розвитку в цілому - і об'єктом інших суміжних наук - окремими сторонами дитячого розвитку» (Педологія...). 
Однією з головних причин кризи у сучасній йому педології Л.С. Виготський вважає старі методологічні засади дослідження. «Той хто уважно дослідить історію виникнення і завмирання педології на першому їі етапі існування, той, навіть нічого не знаючи про наступні етапи іiі розвитку, безумовно має прийти до висновку, що на старій методологічній основі педологія не могла не виникнути, але також не могла й не умерти, що питання про створення i розвиток педології нерозривно пов'язане 3 питанням про побудову іiі на зовсім іншій, принципово непримиренній зі старою методологічній основі» (Педологія...).

Педологія в якості самостійної науки про розвиток дитини може оформитися лише на новій методологічній основі, на основі нового розуміння свого предмету. «Цілісність (нові якості і закономірності, що представлені синтезом (тут і далі підкреслено нами - П.В.Г.) окремих аспектів i процесів розвитку, спеціальна установка на розкриття і дослідження взаємозалежностей, зв'язків і відношень, які лежать в основі цього синтезу), розвиток, який розуміється не як збільшеннязменшення, але як саморух і боротьба протилежностей, є двома основними моментами, що визначають методологічну установку педології в цілому і у кожному окремому іiі дослідженні» (Педологія...). «Педологія - зазначає автор - неможлива ні на основі метафізичних, формально-логічних поглядів на дитячий розвиток, які припускають лише механістичне об'єднання окремих сторін розвитку, ні на основі дуалістичних поглядів на природу людини, які закривають шляхи дослідження тієї реальної єдності, якою є процес дитячого розвитку. Саме цьому педологія фактично померла на Заході і в Америці як особлива наука...» (Педологія...).

«Тенденція до виникнення педології...починається 3 того, що окремі науки, навіть у своїй формально-логічній обробці окремих аспектів дитячого розвитку, стихійно наштовхувались 
на діалектичний характер феноменів, які вони вивчали, на синтез i на розвиток як на джерело пошукуваних закономірностей» (Педологія...).

Особливе значення Л.С. Виготський приділяв зв'язкам і взаємовпливам педології i сучасної йому психології. «Розв'язуючи питання про відношення педології і психології ми, тим самим, розв'язуємо питання про методологічну природу кожної з цих двох наук» (Педологія...). «Принцип практики», який «тиснув» на психологію, спонукаючи іiї до розділення на дві самостійні наукові дисципліни, настійливо вимагав перегляду старих методологічних позицій як власне класичної тогочасної психології, так і нової науки про дитячий розвиток педології. «...Ті принципи, які ми кладемо в основу педології, принципи цілісності i розвитку, $\epsilon$, власне, й принципами сучасної психології, яка, як відомо, також будується на ідеях цілісності і розвитку. Але суть справи полягає у тому, щоб ці загальні для логіки усякої науки поняття цілісності, розвитку, синтезу конкретизувати у застосуванні до об'єкту кожної даної науки» (Педологія...).

«Справа не у цілісності і розвиткові взагалі, але у педологічній цілісності і у педологічній концепції розвитку, що охоплює усі сторони розвитку дитини в їх синтезі» (Педологія...).

«Власне дослідження синтезу не є привілеєм педології. Строго кажучи, об'єкт усякого наукового дослідження уже є продуктом синтезу, оскільки він $є$ продуктом розвитку» (Педологія...).

«Тут залишається без відповіді основне питання: у чому синтез? Чи здійснюємо ми його подумки, чи він існує в дійсності. Синтез - це обробка матеріалу чи об'єкт дослідження і врешті, де цей синтез: в голові дослідника чи у розвиткові дитини? Без відповіді на це основне питання ... ми не можемо правильно підійти до усієї проблеми взаємовідносин педології і суміжних з нею наук в цілому» (Педологія...). 
«... ми можемо у цій роботі тільки підійти до ... проблеми синтезу, не розкривши навіть першої сторінки книги, що нас зацікавила» (Педологія...).

«Ми зараз переживаємо новий етап у розвитку нашої науки... Ми підходимо від синтезу, від цілісного розвитку дитини. I якщо синтез не $\epsilon$ пустим словом, а означає реально існуючий у природі дитячого розвитку факт, то педологія набуває у визнанні цього факту свою непохитну об'єктивну міцну основу» (Педологія...), - це були останні слова аналізованої роботи Л.С. Виготського.

Таким чином, видатний психолог сформулював завдання для подальших досліджень щодо проблеми синтезу у психології. А саме: «... де цей синтез: в голові дослідника чи у розвиткові дитини?». Іншими словами: чи $є$ синтез одним 3 логічних прийомів, що складають цілісну філософську методологію наукового пізнання психічної реальності, чи реально існуючим, дієвим механізмом психічного розвитку, механізмом, який забезпечує функціонування психічних процесів i породжує психічні новоутворення в індивідуальному розвиткові кожної конкретної людини.

Синтез - уточнення поняття (процес, явище,

\section{результат).}

Поняття «синтез» застосовується у багатьох, майже у всіх відомих нам науках - філософії, біології, хімії, фізиці, мистецтвознавстві, естетиці, геології та ін. Цікаво, що у психології це поняття майже не застосовується. Виключення складає хіба-що теорія психосинтезу Р. Ассаджиолі (2002), хоча iii аналіз показав, що поняття «синтез» тут застосовано не в якості методологічного засновку, а скорше як приваблива назва. Сама ж теорія Р. Ассаджиолі, на наш погляд, може бути віднесена до пулу теорій гуманістичної психології.

У геології синтез - це процес штучного утворення мінералів та вирощування монокристалів 3 окремих елементів чи хімічних 
сполук у лабораторних або промислових умовах (Словник української мови: 186), з'єднання простих хімічних елементів, що мають певні властивості, у більш складні, які мають інші властивості.

У хімії синтез - це одержання або утворення складних хімічних речовин шляхом сполучання простіших речовин або елементів (Словник украӥнської мови: 186). Наприклад: під впливом рослинності в грунті постійно виникає синтез мінеральних сполук і утворення органічних речовин.

Вода $\left(\mathrm{H}_{2} \mathrm{O}\right)$ є результатом синтезу двох молекул водню $\mathrm{i}$ однієї молекули кисню. При цьому і водень і кисень, узяті окремо, мають певні специфічні властивості: молекулярну вагу, агрегатний стан, температуру кипіння, температуру замерзання, інші фізичні і хімічні властивості. Вода ж, як результат синтезу, має свої специфічні властивості (молекулярну вагу, агрегатний стан, температуру кипіння, температуру замерзання, інші фізичні і хімічні властивості), які не є простою сумою двох хімічних елементів, що іï складають. Вона за своїми фізикохімічними властивостями являє собою нову речовину і суттєво відрізняється і від водню, і від кисню.

У ядерній фізиці синтез - це процес об'єднання ядер хімічних елементів у одне ядро з поглинанням або вивільненням енергії. Найбільш відомим прикладом синтезу тут є об'єднання двох ядер водню (разом з їх електронами) в одне ядро гелію. Новоутворений хімічний елемент - гелій, за своїми властивостями суттєво відрізняється від водню. Відомо, що ядерний синтез є основною реакцією, що відбуваються у зірках.

Філософія, як методологічна основа сучасної науки, розглядає синтез в якості логічного прийому, за допомогою якого ми мислено сполучаємо в одне ціле розчленовані в процесі попереднього аналізу окремі частини предмета, процесу або явища (Словник украӥнської мови: 186). Синтетичний підхід в процесі пізнання передбачає, вміння побудувати цілісний 
образ, модель досліджуваного предмета. «...ціле не зводиться до суто механічної суми його частин, оскільки одні й ті самі елементи цілого можуть характеризуватися неоднозначними взаємозв'язками та взаємодіями. Саме на виявлення принципів систематичної єдності окремих сторін та складових частин об'єкта спрямований розумовий синтез як метод пізнання. При цьому об'єкт розглядається вже не просто як синкретична, нероз'єднувана цілісність, а як функціональна впорядкованість форм організації об'єкта та взаємозв'язку його істотних характеристик» (Філософський енциклопедичний словник, 2002: 19).

У Британській енциклопедії знаходимо наступне визначення: «Синтез у філософії - поєднання частин або елементів для того, щоб сформувати більш повне уявлення про предмет або систему. Когерентне ціле, яке виходить в результаті, розглядається як таке, що більше відповідає дійсності, ніж просто набір частин. Термін синтез, в діалектичній філософії німецького філософа 19-го століття ФГП Гегеля, відноситься до більш високого ступеня істини, що поєднує в собі істину тези і антитези» (Britannica, електронне посилання).

Отже, 3 наведених прикладів логічно випливає закономірний висновок: синтез розглядається у двох якостях (аспектах) - як реально існуючий процес оточуючої нас дійсності (фізичні, хімічні, біологічні процеси) і як наше уявлення, як метод пізнавальної діяльності людини (метафізичні процеси).

У природному світі результатом синтезу є нові об'єкти, явища, стани, речовини. Останні не є результатом простого складання, синергії, механічного об'єднання частин або складників, це якісно нові явища, об'єкти, речовини, що несхожі на суму частин, які стали підгрунтям для їх виникнення. Сукупність властивостей і якостей нових об'єктів чи речовин не 
є простою сумою властивостей і якостей речовин, які стали основою для їх створення.

У метафізичному світі результатом синтезу $\epsilon$ нові утворення - знання, уявлення, образи, міфи та інші «духовні продукти». Особливо це знайомо фахівцям, що досліджують проблеми творчості, фантазії, уяви і т.п. Разом з цим, окремо необхідно розглядати синтез як один з методів пізнання, у якості частини наукової методології. Без застосування методів (процесів) синтезу людське пізнання стає принципово неможливим як на рівні людства в цілому, так і на рівні індивідуальної свідомості (Л. Виготський, Л. Вітгенштейн, Ф. Гегель, I. Кант, Е. Кондільяк, К. Маркс, Б. Рассел, В. Роменець, Г. Щедровицький).

Синтез як логічний пізнавальний науковий метод застосовується для: систематизації і співорганізації різноманітних знань про деякий предмет задля застосування у практичній діяльності; з метою трансляції знань про предмет у процесі навчання, виховання, професійної підготовки; створення «багатопанорамної», цілісної картини досліджуваного об'єкта (Г. Щедровицький, 2015). «Коли накопичено достатньо велике число таких «односторонніх» та окремішніх знань, [закономірно] виникає особливе теоретичне завдання об'єднати їх в багатоманітному знанні про об'єкт» (Щедровицький, 2015: 63).

Якраз третій тип синтезу (за Г.П. Щедровицьким) і $\epsilon$ предметом методологування 3 метою побудови цілісного «багатопанорамного» уявлення про об'єкт психологічної теорії на основі різноманітних, парціальних знань про психічні процеси і психічні стани, риси і якості особистості. Про це ж саме говорив у свій час і Л.С. Виготський. Таке завдання ставила перед собою дуже невелика кількість дослідників у психології, адже на шляху синтезу знань у психології, як 3'ясувалось, існує кілька суттєвих перепон і ускладнень. 
«...сам по собі факт наявності декількох теоретичних уявлень, одержаних незалежно одне від іншого при вирішенні різних завдань, ще не дає достатніх підстав для постановки питання про можливий зв'язок між цими уявленнями» (Щедровицький, 2015: 67). Це є однією 3 перепон на шляху синтезу різних теорій у психології. Тому що «всякий спосіб синтезу знань виявляється жорстко пов'язаним із специфічним способом їх отримання» (Щедровицький, 2015: 67). «Отже, головне [полягає] в тому, щоб існували процедури переходів (підкреслено В.П.) між різними уявленнями і знаннями, а це означатиме одночасно можливість встановлення між ними певних зв’ язків (підкреслено В.П.)» (Щедровицький, 2015: 67).

Таким чином, завданням сучасних дослідників $\epsilon$ застосування загальнонаукової методології (прийому) синтезу знань до проблем конкретної науки, у даному випадку психології. Це, власне, і було метою даної роботи.

Розвиток ідей Л.С. Виготського.

Реальний і результативний синтетичний підхід до об'єкту дослідження знаходимо у роботах Л.С. Виготського («Психологія мистецтва», «Педологія підлітка»), зокрема - у його теорії розвитку (Виготський, 1984, 1986). Якщо оглянути в загальному пророблену теоретичну роботу автора у сфері психічного розвитку особистості, то не можна не помітити основних методологічних засад, які якраз і забезпечили синтез знань сучасної йому психології, вікової фізіології, соціології, педагогіки та інших споріднених наук. Цей синтез став основою прориву, переходу на інший, вищий рівень розуміння драматургії індивідуального розвитку дитини (Божович, 1968, Berk, 1994, Moll, 1994).

Першою ознакою синтетичного методологування, як було зазначено, є вихід за межі однієї вузької наукової дисципліни. У даному випадку - психології. Теорія розвитку Л.С. Виготського грунтується на міждисциплінарному підході i містить 
результати досліджень дитячого розвитку різними науковими дисциплінами.

Друга ознака - вихід за межі власне однієї теорії і встановлення міжпредметних функціональних зв'язків, які якраз і дозволили представити картину індивідуального розвитку в іiі цілісності, в сукупності фізіологічних, психологічних, соціальних і культурно-історичних факторів і умов.

Третьою ознакою i, одночасно - результатом, стало запровадження нових понять i категорій, які уможливили розуміння сутності i психологічних механізмів розвитку: «соціальна ситуація розвитку», «новоутворення», «провідний вид діяльності», «зона найближчого розвитку», «вікова криза розвитку» і т.п (Виготський, Т.4, 1984).

Четвертою ознакою є прогностичність теорії розвитку що, власне, i відкриває реальні можливості практичного психологічного супроводу розвитку дитини психологічною службою (Панок, 2012). Саме прогностичний потенціал теорії розвитку дає підстави вважати психологічну науку власне наукою, а не сукупністю уявлень окремих дослідників про окремі явища і процеси у психічному житті людини.

3 часів Л.С. Виготського жодна 3 теорій розвитку особистості в онтогенезі, на нашу думку, навіть не наблизилась у своїй інтерпретації означених процесів через єдину причину відсутність методології синтезу в узагальненні результатів емпіричних і теоретичних досліджень.

\section{Синтез як пізнавальний принцип у психології.}

Синтез, як пізнавальний метод, декларується практично в усіх наукових психологічних дослідженнях. Але чи реалізується він уповні і завжди - велике питання. Адже екстраполяція, механічне об'єднання окремих рис і якостей особистості у симтомокомплекси, виокремлення типів особистості, іiі структури, де також має місце механічне об'єднання окремих іiі 
рис, не можуть вважатися синтезом у повному розумінні цього слова.

У психології об'єкт дослідження - психіка в цілому, або особистість, або свідомість, зазвичай досліджуються аналітично, шляхом дослідження окремих функцій, рис, властивостей, процесів. В результаті одержується доволі різноманітна, іноді суперечлива, картина, сума знань, що мало пов'язані між собою. За тим дослідники намагаються поєднати ці односторонні знання про окремі аспекти досліджуваного явища у цілісну систему - образ об'єкту дослідження.

Такий тип систематизації, або - спроби синтезу, описано Г.П. Щедровицьким у цитованій роботі: «Методологічний засновок такого подання об'єкта (хоч він здебільшого не виявляється у явному вигляді) полягає у тому, що кожна із зафіксованих у знанні властивостей трактується як відображення субстанційної частини об'єкта, а реальна система об'єкта розуміється як «складена» із цих частин. При цьому формальні зв'язки об'єднання, встановлювані у площині знань, просто переносяться «всередину» самого об'єкта й оголошуються його структурними зв'язками» (Щедровицький, 2015: 63).

Найбільш показовим прикладом такого типу синтезу знань, на наш погляд, $є$ теорії особистості, які зазвичай відносять до групи «теорій рис особистості» (Г.Ю. Айзенк, Р. Кеттел, Г. Олпорт, В.В. Рибалка, В.Ф. Моргун та ін..). Ці дослідники, базуючись на різних теоретичних позиціях, виокремлюють певну кількість особистісних рис чи якостей (від 4 до 150). При цьому останні являють, на їх думку, цілісну систему взаємопов'язаних елементів. У цій групі теорій особистості зустрічаються як одномірні моделі, так і багатомірні.

В опозиції до названих теорій знаходяться психоаналітичні і гуманістичні теорії, які принципово не звертаються до проблеми окремих рис особистості чи психічних процесів. 
Натомість їх дослідження фокусуються на архетипах, рівнях психічного відображення навколишньої дійсності, ієрархії потреб особистості, життєвому цілепокладанні, смисложиттєвих орієнтаціях, «акме» і т.п. (Р. Ассаджиолі, Г.О. Балл, А. Ленгле, А. Маслоу, К. Роджерс, В. Франкл, 3. Фрейд, К. Юнг та ін..) і грунтуються в основному на некласичній або постнекласичній методології.

Взагалі, психологічні теорії особистості $є$ надзвичайно багатим матеріалом для методологічного аналізу в цілому i, особливо, 3 точки зору розкриття механізмів синтезу як рушійної сили розвитку особистості, виникнення нових якостей i рис, формування симптомокомплексів, компенсацій, захистів, витіснень і т.п. Іншими словами - синтез, синтетичний підхід може забезпечити «психологічну динаміку» замість «психологічної статики» у теоріях особистості.

Заглиблюючись у проблему синтезу як реального процесу, що відбувається в психіці, а не «в голові дослідника», розглянемо категорію образу як найбільш фундаментального поняття у психології ( і не тільки в ній!).

«Образ (лат. species - вид) - у схоластичній концепції пізнання, а також у відповідних концепціях професорів КМА species - це сполучна ланка між суб'єктом і об'єктом пізнання, завдяки якій суб'єкт і об'єкт пізнання, хоча й залишаються реально різними, але набувають єдності. Заміняючи предмет, річ, образ поєднується з суб'єктом пізнання завдяки тому, що має той чи інший ступінь подібності до предмета пізнання. Ці образи поділяються на чуттєві, в яких присутній максимум ознак індивідуальних речей, та умоосяжні. Повна дематеріалізація чуттєвих образів досягається в процесі їхнього опрацювання інтелектом. Процес абстрагування, що позбавляє чуттєві образи індивідуальних ознак і виявляє родові й видові форми речей, трансформує ці чуттєві образи в образи умоосяжні. Останні уявлялися як суто духовне існування форм, 
вивільнених у процесі пізнання від своїх тілесних оболонок, в яких вони, на думку тогочасних вчених, існують в реальній дійсності.» (Я. Стратій (Філософський енциклопедичний словник: 499).

Класичне уявлення про образ у психології полягає у тому, що образ $є$ сукупністю відчуттів які одержуються в результаті сприймання. Наведемо два, найбільш поширених визначення.

«Сприйняття грунтується на чуттєвих даних відчуттів, які ми отримуємо від наших органів відчуття під впливом зовнішніх подразників, що діють у даний момент... Але сприйняття разом $з$ тим і не зводиться до просто суми відчуттів. Воно завжди $є$ більш або менш складним цілим, якісно відмінним від тих елементарних відчуттів, які входять до його складу» (Рубинштейн, 1946: 244).

Для більш глибокого розуміння сутності процесу сприймання і його результату - сприйняття, звернімося до статті Л.Ж. Веста, В. Епштейна і В.Н. Дембера «Perception» у Британській енциклопедії (Периепція...).

Автори визначають сприйняття як «процес, що впорядковує/транслює сенсорну стимуляцію в організований досвід» (Периееція...). Процес приймання полягає, на думку авторів, у перетворенні окремих сенсорних стимулів, іноді різних модальностей - звукових, світлових, тактильних, у цілісний образ, який, у свою чергу, стає частиною індивідуального досвіду людини (сприйняття).

(Тут необхідно зробити термінологічне уточнення. В англійській, як і в російській, «perception» i «восприятие» застосовуються у розумінні опису власне процесу та, одночасно - результату перцептивної активності індивіда. В український існують окремі поняття: сприймання - характеристика процесу, сприйняття - характеристика результату.).

«Сприймання - чуттєве осягнення предметів та явищ дійсності в сукупності притаманних їм властивостей та 
особливостей при безпосередній їх дії на органи чуття. Чуттєве джерело сприймання - відчуття, опертя на яке характеризує сприймання як процес формування образу предмета i як результат цього процесу - сам образ. У сприйманні, окрім безпосередньо-буттєвого цілісного охоплення предмета пізнання, включається і процес його усвідомлення як перехід до мислительних форм осягнення дійсності». (С. Андрос (Філософський енциклопедичний словник: 631)).

Підводячи підсумки аналізу проблеми сприймання/сприйняття i породження цілісного образу навколишньої дійсності необхідно згадати слова Л.С. Виготського, який говорив, що вищі функції «будуються зазвичай не поряд з елементарними функціями, як нові члени у тому ж ряду, і не над ними, як вищий поверх мозку над нижчим, вони будуються по типу виникнення нових складних сполучень елементарних функцій, шляхом виникнення складних синтезів» (Выготский, 1984: 112).

«... вищі функції виникають не інакше як на основі нижчих: у кінцевому рахунку вони являють собою не фізіологічні процеси нового сорту, а відоме складне сполучення, складний синтез тих же елементарних процесів» (Выготский, 1984: 112).

Таким чином, узагальнюючи розлоге цитування яке, тим не менше має тут певний логічний смисл, можемо констатувати, що проблема виникнення образу 3 сукупності відчуттів у процесі сприймання має усі ознаки синтезу як реально діючого психічного механізму. А саме: систематизація та об'єднання окремих відчуттів в єдину структуру - образ («встановлення зв'язків» між окремими відчуттями); образ не є простою сумою відчуттів, а якісно новою психічною функцією (явищем); у створенні образу беруть участь інтелектуальні процеси (мислення) і тому образ, на відміну від елементарних відчуттів, $\epsilon$ культурно-історичним явищем, має суспільну природу; в 
образі знаходить своє вираження не стільки особистість, скільки індивідуальність кожної конкретної людини.

Синтез якмеханізм розвитку в онтогенезі.

По-суті тут ми маємо відповісти на одне фундаментальне питання: куди зникають риси і якості особистості при переході від однієї стадії вікового розвитку до іншої? Чи вони зникають не залишивши по собі й сліду, чи перетворюються у щось інше? Чи знаходяться у латентному, інактивному стані, чи слугують матеріалом 3 якого створюється щось нове, не схоже на сукупність рис і якостей, які були притаманні попередньому віковому етапу? На основі чого виникають вікові новоутворення? За рахунок синтезу існуючих у особистості рис i якостей, чи за рахунок інтеріоризації соціального досвіду і соціальних впливів? Що дає енергію для цього? Чи ця енергія закладена в особистості імпліцитно? Чому метелик не нагадує нам гусінь 3 якої він утворився, а підліток схожий на дитину, якою він був ще кілька місяців тому? Чому і в підлітка і в дитині уловлюються риси унікальної людської індивідуальності?

Насправді перше питання є фундаментальним, а інші лише уточнюють, деталізують його, хоча кожне з них вимагає від нас фундаментальних відповідей, а, значить - фундаментальних досліджень.

Розглянемо для прикладу перехід від старшого дошкільного віку до молодшого шкільного. Відомо, що провідним видом діяльності старшого дошкільника $є$ рольова гра, яка власне i визначає увесь смисл індивідуального розвитку особистості у цей період, усі найбільш важливі новоутворення (Виготський, 1984; Божович, 1968; Berk, 1994). У рольовій грі відбувається низка процесів, які стають підгрунтям для реалізації майбутнього новоутворення молодшого школяра - соціальної позиції учня. Роль учня - це перша в житті людини суспільно значуща роль, від якої, у переважній більшості, залежить увесь процес соціалізації особистості у початковій школі. Саме роль 
учня забезпечує присвоєння соціально-історичного досвіду людства через опанування основами наукових знань - учіння, формування системи цінностей та інтересів, формування засад соціальної поведінки та міжособистісного спілкування. Реалізація ролі учня спонукає особистість до формування довільних форм поведінки і «елементарних психічних процесів» - уваги, емоційної регуляції, волі, пізнавальної мотивації та ін.. Відбувається це завдяки розвиткові навичок особистісної рефлексії як одного 3 механізмів формування самосвідомості особистості.

Отже, повертаючись до рольової гри у старшому дошкільному віці, зазначимо, що усі названі новоутворення особистості молодшого школяра у повній мірі залежать від того, наскільки розвинутою і продуктивною, в смислі продуктивності розвитку рис особистості, буде сама ця рольова гра.

Дослідники цього вікового періоду (Божович, 1968; Berk, 1994; Moll, 1994) відзначають, що смисл рольової гри полягає в опануванні дитиною соціальних відносин, які вона може спостерігати серед дорослих. В процесі відігрування елементів тих чи інших соціальних ролей, які спостерігає дитина у своєму повсякденному житті, вона практично освоює такі елементи як: формальні (зовнішні) ознаки соціальної ролі, рольові очікування, умовність соціальної ролі і її відстороненість від суб'єкта рольової поведінки, рольовий репертуар, соціальна значимість тієї чи іншої соціальної ролі, соціальні вимоги до тієї чи іншої соціальної ролі та ін.. Таким чином, через рольову гру здійснюється опанування дитиною міжособистісних відносин, соціальних стосунків, соціальних правил поведінки і соціальної взаємозалежності людей, присвоєння й інтеріоризація культури в широкому розумінні цього слова.

У старшого дошкільника названі елементи не складають цілісної системи, єдності, а представлені фрагментарно, знаходячись у зоні найближчого розвитку особистості. При 
переході від дошкільної освіти до систематичного шкільного навчання відбуваються глибокі трансформації. Передусім змінюється соціальна ситуація розвитку яка спонукає дитину до виконання конкретної соціальної ролі - ролі учня. Умови цієї соціальної ситуації мають як заохочувальні, так і санкційні аспекти, - дорослі змушують дитину відігрувати цю роль. Заохочувальними моментами $є$ прагнення самої дитини стати учнем, іiі інтерес до набуття нового статусу, зацікавленість стосунками в умовах освітнього закладу. Тут необхідно наголосити на такому важливому чиннику ситуації як соціальний тиск, соціальні очікування, які виражаються у вимогах дорослих 3 найближчого соціального оточення до дитини - «Ти ж учень». «Ти маєш добре вчитися». «Ти маєш виконувати завдання вчителя». Таким чином, соціальна ситуація детермінує пошук внутрішніх ресурсів особистості - знань, соціальних навичок і уявлень, навичок у реалізації тих чи інших соціальних ролей, навичок соціальної перцепції, пов'язаних із рольовою поведінкою і т.П., досвід рольової поведінки, що був набутий у процесі рольової гри. 3 усіх цих окремих елементів складається комплекс рольової поведінки під назвою «учень» і прийняття умов ролі - позиція учня.

Тут важливо зазначити, що назване новоутворення не $\epsilon$ простою сумою окремих елементів досвіду, рис і якостей, а представляє собою цілісне утворення, що вирішальним чином впливає на формування таких нових якостей як довільність, рефлексія, самооцінка i т.п. Іншими словами - тут ми спостерігаємо результат синтезу окремих елементів, що сформувались на попередньому етапі вікового розвитку, в єдину цілісну структуру соціальної ролі «учень», якісні властивості якої не дорівнюють простій сумі елементів 3 яких вона виникла. Особистість дитини зазнає якісних змін, виходить на новий щабель індивідуального розвитку. 
«Новоутворення, що одного разу виникли в свідомій особистості дитини, приводять до того, що змінюється сама ця особистість, що не може не мати самих суттєвих наслідків для подальшого розвитку.... бо дитина, яка змінила будову своєї особистості, є вже іншою дитиною, соціальне буття якої не може не відрізнятись суттєвим чином від буття дитини більш раннього віку» (Виготський, 1984: 259).

Таким чином, маємо визнати, що механізми синтезу лежать в основі об'єктивного процесу індивідуального розвитку особистості, забезпечуючи їй перехід від одного вікового етапу до іншого, більш високого. Отже, маємо підстави стверджувати, що синтез відбувається не тільки у метафізичній сфері, а він $\epsilon$ реальним процесом, який забезпечує розвиток кожної конкретної особистості в онтогенезі.

\section{Синтез як принцип у прикладній психології.}

Прикладна психологія - специфічний вид психологічної діяльності, iї визначення останніми роками доволі широко застосовується (Панок, 2017). Можливо, тут необхідно сказати, чим вона не $\epsilon$. Вона не $є$ тільки однією з психологічних теорій, вона не $є$ одним з видів психологічного практикування, скоріше - вона є певною методологією, яка дозволяє узагальнити як теоретичні, так $\mathrm{i}$ практичні знання $\mathrm{i}$ досвід на основі застосування процедур синтезу. Саме синтез, на нашу думку, $\epsilon$ головною відмінністю прикладної психології, іï ядром.

Принцип синтезу пронизує всю структуру прикладної психології і на рівні розуміння її предмету (психологічні теорії), i на рівні методів психологічного дослідження (обстеження), і на рівні методів психологічного практикування (психологічна корекція, психотерапія).

«Принцип практики» змушуе психолога-практика змішувати, порівнювати, синтезувати у своїй професійній свідомості елементи різних психологічних теорій для адекватного розуміння явищ, 3 якими він працює. У процесі 
професійної рефлексії, на супервізійних сесіях, доволі розповсюдженим явищем $\epsilon$ застосування психологамипрактиками понять i категорій 3 різних психологічних концепцій. Більше того, саме пояснення механізмів, з якими він мав справу, часто запозичується з різних психологічних теорій, або, навіть, позапсихологічних чи побутових. Таким чином, синтез на рівні теорії, на рівні усвідомлення і розуміння психічних явищ, які $\epsilon$ предметом психологічного практикування, є необхідністю для практиків.

Психодіагностика $€$ однією 3 найважливіших функцій практичного психолога. Разом 3 тим, існують два види психодіагностики - науковий (статистичний) i прикладний («клінічний»). Якщо результатом першого є закономірність, психічна норма, яка притаманна певній популяції, то результатом другого є діагноз - цілісний образ конкретної людської індивідуальності. Як ми вже розуміємо, останній є продуктом синтезу.

Методи психологічного практикування (психологічна корекція або психологічна терапія) також грунтуються на синтетичному поєднанні методів, методик і прийомів наукової, ужиткової i, навіть, позанаукової психології. Іноді буває важко ïx розрізнити у межах однієї методики (Панок, 2017).

Таким чином, можна констатувати, що без принципу синтезу, без синтезування прикладна психологія втрачає усякий смисл. Психологічне практикування без синтезу також $\epsilon$ неможливим. Отже, синтез $є$ тим фундаментом завдяки якому тільки й можлива будівля прикладної психології і психологічної практики, до яких би «шкіл» чи теорій вони себе не відносили.

Синтез як дидактичний принцип у підготовці практичних психологів.

Сучасний стан підготовки психологів грунтується в основному на аналітичній методології. Можемо подивитись на 
зміст підготовки спеціалістів у любому університеті і, навіть по окремо взятому предметі.

Проблема підготовки практичних психологів полягає у тому, що жодна система підготовки, жоден окремий предмет не ставить собі за мету синтезувати парціальні знання про психіку - предмет психологічного практикування, у цілісну внутрішню картину цього предмету у свідомості випускника-психолога. Парціальність, фрагментарність знань зберігається як на рівні загального уявлення про предмет, так і на рівні застосування методів психологічного практикування. За нашими спостереженнями - якщо такий синтез і відбувається, то відбувається він стихійно, несвідомо як з боку викладача, так і 3 боку студента.

Професійна підготовка майбутніх психологів-практиків може бути ефективною тільки у поєднанні аналізу і синтезу окремих знань про людину. Інтегруючим поняттям цього процесу i, одночасно його результатом, має бути індивідуальність клієнта (пацієнта).

Думка про поєднання методології аналізу і синтезу в процесі професійної підготовки практичних психологів не $є$ новою. У свій час, ще на початку 90-тих, ми, долучившись до цієї дискусії, запропонували своє бачення (Основи..., 1999). Воно полягало у запровадженні трьох стадій/етапів засвоєння психології студентами. Перший - аналітичний, який передбачає вивчення класичних психологічних тем: психофізіологія, психічні процеси, стани, риси і якості особистості, їі типологія, методи психологічного дослідження, соціальні стосунки, історія психології як наукової дисципліни, нейропсихологія і т.п. Другий - синтетичний, основу якого складає вчення про індивідуальність, унікальність і неповторність кожної окремої особистості, індивідуальну історію - життєвий шлях, життєві обставини - життєву ситуацію, життєві перспективи людини і іï долю. На цьому етапі відбувається синтезування окремих знань, 
що були одержані на попередньому етапі, у цілісні

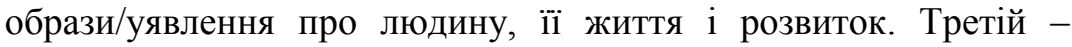
методичний, який передбачає засвоєння методів психологічного практикування, прикладну (клінічну) психодіагностику i психологічну корекцію (терапію).

Таким чином, професійна підготовка практичного психолога може вважатися успішною тільки за умови синтезу різноманітних психологічних знань, теорій, концепцій, з однієї сторони, і синтезу різних методів і прийомів психологічного практикування - 3 іншої. Для того, щоб це забезпечити, програми підготовки спеціалістів мають бути суттєво переглянуті, а одним із завдань викладачів має стати формування у студентів синтезованої картини предмету їх майбутньої професійної діяльності - індивідуальності конкретної людини.

\section{Висновки.}

1. Л.С. Виготський вважав синтез тим методологічним «ключем», який здатний розв'язати проблему кризи у психології. Аналіз методології наукових досліджень видатного психолога довів, що саме синтез є тим засновком, на якому будуються не окремі роботи дослідника, а уся його творчість. Синтетичний підхід, синтетичне розуміння сутності і динаміки розвитку особистості $\epsilon$ наріжним каменем методології Л.С. Виготського. Він протиставив старій аналітичній методології, що панувала на той час у психології, нову парадигму - синтетичну, намітивши тим самим нові шляхи іiі розвитку, шляхи подолання кризи.

2. Поняття синтезу застосовується у науці у трьох площинах: як реальні процеси, що відбуваються у живій i неживій природі; як процеси, що забезпечують створення якісно нових продуктів у метафізичній царині - освіта, культура, музика, літературна творчість і т.п.; як складова філософської 
методології пізнання довколишньої дійсності, як прийом мисленнєвої діяльності і творчості вченого.

У психології синтез ще не набув належного йому місця ні в теорії, ні в експериментальній практиці, ані як значуща методологема, що відкриває широкі можливості для подальшого розвитку.

3. Застосування методології синтезу до розуміння конкретних проблем розвитку психологічної науки i психологічної практики дає змогу обгрунтовано стверджувати:

3.1. Процеси синтезу - це реальні процеси, що відбуваються у психічній реальності людини як на рівні елементарних психічних процесів i функцій, так i на рівні особистості, індивідуальності. Таким чином, можна стверджувати, що синтез $€$ «реальним психічним фактом» (Л.С. Виготський). Саме синтез $€$ тим психічним механізмом, який забезпечує виникнення психічних новоутворень - нових рис і якостей особистості, забезпечуючи таким чином їі (особистості) саморозвиток.

3.2. Синтез, синтетичний підхід до усвідомлення фактів психічного життя людини $\epsilon$ наріжним каменем, головним методологічним принципом прикладної психології. Без синтезування різноманітних форм, видів i наративів психологічного знання - 3 однієї сторони, i досвіду психологічного практикування (вправляння) - 3 іншої, прикладна психологія втрачає усякий смисл і перетворюється на іще одну теорію.

3.3. Основою професійної підготовки практичного психолога (психолога-практика) $є$ формування його синтетичних здатностей, уміння синтезувати різноманітні теоретичні уявлення i різнопланові факти та результати клінічної діагностики у цілісну картину буття i розвитку людської індивідуальності. Наголосимо: індивідуальності конкретної людини. Тільки на основі такої парадигми стає можливим застосування конкретних методів психотерапії i 
психокорекції і, врешті решт, - формування професійної інтуїції як вищого щабеля професіоналізму.

Для психології проблема синтезу $є$ невичерпною. Зауважимо, що за Г.П. Щедровицьким існує декілька типів синтезу, які застосовуються 3 різною метою - навчальної, пізнавальної і практичної діяльності, тому ближчими завданнями в галузі теоретичної психології може бути застосування цих синтезів для різних напрямів психологічних досліджень і практики. Очевидно, що різні типи діяльності у царині психології - наукова, навчальна, прикладна, практична, потребують різних типів синтезу. Якщо психологія хоче здолати кризу методології, синтез $є$ необхідною умовою цього подолання.

\section{Література}

Ассаджиоли Р. (2002). Психосинтез. Принципы и техники. М: ЕКСМО-Пресс.

Божович Л.И. (1968). Личность и ее формирование в детском возрасте. М.: Просвещение.

Выготский Л.С. (1984). Собрание сочинений: в 6-ти т. Т. 6. Научное наследство. М. : Педагогика.

Выготский Л.С. (1984). Собрание сочинений: В 6-ти т. Т. 4. Детская психология. М. : Педагогика.

Панок В.Г. (Ред.) (1999) Основи практичної психології: Підручник для студентів ВЗО. К.: Либідь.

Панок В.Г. (2010). Практична психологія. Теоретикометодологічні засади розвитку. Монографія. Чернівці: Технодрук.

Панок В.Г. (2012). Психологічна служба : Навчально-методичний посібник для студентів і викладачів. Кам'янець-Подільський : ТОВ Друкарня Рута.

Панок В.Г. (2017). Прикладна психологія. Теоретичні проблеми : монографія. К.: Ніка-Центр.

Рубинштейн С.Л. (1946). Основы общей психологии. М. : ГУ-ПИ.

Словник української мови. (1978). Академічний тлумачний словник : в 11 томах. Том 9, С. 186. 
Шинкарук В.І. (Ред). Філософський енциклопедичний словник. (2002). К.: Абрис.

Щедровицький Г.П. (2015). Синтез знань: проблеми і методи. Психологія і суспільство. № 2 (60). С. 61-83.

Berk, L. E. (1994). Child Development. Third Edition. Boston: Allyn and Bacon. pg. 50, 156-157, 254, 352.

Moll, Louis C. (1994). Vygotsky and Education: Instructional implications and applications of sociohistorical psychology. New York: Cambridge University Press.

Синтез. Режим доступу. http://www. Britannica. com/EBcheked/578628/synthesis

Сприйняття. Режим доступу: http//www.britannica.com/topic/perception

Педологія. Режим доступу. http:/psychlib.ru/mgppu/periodica/Pedologia071931/NPS012.HTM

Оригінальний рукопис отриманий 12 березня 2019 року

Стаття прийнята до друку 25 березня 2019 року 